\title{
Identification of bacteria responsible for Nitrification and its correlation with physicochemical properties of water resources.
}

\section{Manal M. Abdel-Rahman ${ }^{1}$ and Ibrahim E. Mousa ${ }^{\star}$}

\author{
1- Plant pathology department (Genetic branch), Faculty of Agriculture, Damanhour University, Al- \\ Behera, Egypt.mm.rahman@agr.dmu.edu.eg \\ 2- Environmental biotechnology department, Genetic engineering and biotechnology institute \\ (GEBRI), University of Sadat city, Menoufia, Egypt. \\ Ibrahim.mousa@gebri.usc.edu.eg
}

\begin{abstract}
In this study, many findings were observed by monitoring seasonal variations of physical, chemical and microbiological characteristics of raw water of seven main canals used by Water Purification Plants in Kafr El-Sheikh governorate; those findings elucidated the quality of these resources and how would they become affected by pollutants especially during winter season and low demand period of Nile River. This study discussed nitrification process occurrence and how would this process and those characteristics affect each other. These seasonal changes during winter season are affecting and altering physicochemical and microbiological parameters of raw water in a bad way causing many problems especially in drinking water purification plants located on Nile River and main canals. Identification of ammonia oxidation and degradation responsible bacteria revealed that Nitrosomonas europaea and Bacillus amyloliquefaciens were involved in ammonia removal and nitrification process.
\end{abstract}

\section{INTRODUCTION}

In developing countries, drinking water treatment plants are constructed in order to remove organic compounds in an efficient way by disinfection, coagulation and filtration. These treatments are the common methods applied in water treatment but are not considered advanced enough for nitrogenous compounds removal. So, there are a few techniques available to remove ammonia that are divided into two main categories as physicochemical and biological [Mook et al., 2012]. Physicochemical treatment technologies include ion exchange (IE), reverse osmosis (RO) [Afonso et al., 2004], electrodialysis and activated carbon adsorption [Hilal et al., 2004]. RO is the most use technology that has potential to remove ions, proteins and organic chemicals with high running cost and energy requirement [Kim et al., 2009].

Among all bio-waste types from urban, agriculture and aquacultural industrial sources, fermented municipal bio-waste are the most exploitable ones. The concentration of wastes in water resources collecting natural bio-organic matter is concerning. In addition, anaerobic and/or aerobic processes of this bio-waste allow reducing the content of water and obtaining materials with higher concentration of organic matter. By these features, additional wastes may be defined potential negative cost feedstock [SheldonCoulson, 2011]. Nevertheless, not all processes for attaining these features are clean. A typical example is the anaerobic process of organic waste for the bioremediation. The process converts the nitrogenous fractions of the bio-waste organic matter to less harmful compounds, whereas the carbon fraction remains in the step limiting factor [Nielfa et al., 2005, Wagner et al., 2013, Verma, 2002].

For hydrophilic compounds, its sorption capacity to solids is limited and complete 
removal can only be achieved through their biodegradation, For hydrophobic compounds, sorption to the biomass and subsequent retention of the solids by the membrane filtration are the main removal mechanisms [Xue et al., 2010, Sanguanpak et al., 2015]. Several operational conditions employed in MBRs favor and enhance biotransformation and mineralization of micro-pollutants. MBRs can be operated under long SRT condition as its operation does not depend on sludge settling ability. Long SRT operation allows slow growing microorganisms to adapt which results in high diversity of microbial community including nitrify-ing bacteria in the system [Boonnorat et al., 2014]. Higher biomass concentrations also lead to intensification of biological processes and may increase the interaction between microorganisms and more likely for genetic information exchange to occur. Under higher biomass concentrations, the food to microorganism (F/M) ratio is also lower which could result in more complete mineralization [Boonyaroj et al., 2016].

The number of nitrifiers in complex systems has been traditionally determined by the mostprobable-number (MPN) technique and selective plating. However, these techniques are timeconsuming, often underestimate the number of

\section{MATERIALS AND METHODS}

Water sampling:

Raw water samples were collected seasonally between December 2013 and October 2014 from selected sites located on the seven main canals of Kafr El-Sheikh Governorate, Egypt. Samples were collected manually at about $30 \mathrm{~cm}$ under water surface in appropriate, clean, free of analyst of interest and free of contaminants containers. Suitable amounts of raw water were collected according to each test requirements. Each lab conditions and instructions for sample collection, storage and preservation were exactly followed and performed according to standard methods of water and wastewater [APHA 2005]. The temperature of the sample was maintained at ambient conditions prior to and during testing. nitrifiers, and do not allow discriminations at the species level (Konuma et al., 2001). Depending on the culture medium and incubation conditions, only a fraction of the total nitrifying community can ever be measured by viable counting methods. Therefore, other methods have been developed for in situ identification and enumeration based on the specificity of antibodies and nucleic-acid sequences in order to avoid the limitations of the MPN-technique. Nitrifiers can be detected in environmental samples, independent of their culturability, by using either antibodies or $16 \mathrm{~S}$ rRNA-targeted oligonucleotide probes. The fluorescent antibody technique can be applied for direct microscopic enumeration of nitrifiers in complex environmental samples (Sanden et al., 1994).

This study is aimed to find correlation water quality with nitrifying bacteria and monitoring nitrification as a biological process for ammonia removal proposing an infield solution of ammonia increase in water. For that, the analysis water quality for the seven main canals in Kafr ElSheikh Governorate was carried out to determine the seasonal variation of physical and chemical, biological and microbiological characteristics of water and monitor nitrification process occurrence and the seasonal variation of ammonia oxidizing bacteria in raw water resources.

The collected water was stored and refrigerated at $4^{\circ} \mathrm{C}$ for subsequent testing. The temperature of the sample was adjusted to room temperature before initiating any test. On the other hand, turbidity and $\mathrm{pH}$ were measured in field.

\section{Physical and chemical analyses of water samples:}

The quality of resource water samples was determined after some measurements such as $\mathrm{pH}$ (2510 platinum electrode), turbidity as Nephelometric turbidity units (NTU) (2130), chloride (mg/l) (4500 Argentometeric method), total alkalinity $(\mathrm{mg} / \mathrm{l})$ (2320B titration method), total Hardness (mg/l) (2340B EDTA titration), silicate ( $\mathrm{mg} / \mathrm{l})$ (4500C Molybdosilicate method), phosphate $(\mathrm{mg} / \mathrm{l})$ (4500D Stannous chloride 
method), sulfate (mg/l) (4500E Turbidimetric method). Nitrogen forms as free ammonia $(\mathrm{mg} / \mathrm{l})$ (4500C Sodium nitroprusside method), and Nitrite (4500B colorimetric method) were measured. All the physicochemical analyses were run in duplicates and determined by the procedures recommended in the standard methods for the examination of water and wastewater (APHA, 2005).

\section{Microbiological and biological analyses of water samples \\ The enumeration of total bacterial count (TBC) in water samples was done using the spreading plate technique over Plate count agar medium (tryptone glucose yeast agar) which is high-nutrient agar, widely used medium for heterotrophic plate count. Detection of total and fecal coliform bacteria was based on membrane filter technique using selective media as m- Endo agar and FM- media, respectively, which is base for enumerating membrane filtration. Detection of FS bacteria was based on membrane filter technique using selective media as $\mathrm{m}$ Enterococcus agar base for isolating and enumerating Enterococci in water by membrane filtration.}

\section{Detection of Nitrifying Bacteria}

Detection of nitrifying bacteria was based on the multiple-tube method which is based on selective growth of ammonia oxidizing bacteria in specialized media AOB medium, followed by statistical computations of most probable

Table (1): Oligonucleotide primers sequences used for Identification of Nitrosomonas europaea.

\begin{tabular}{|l|l|l|l|l|}
\hline Primer & Primers sequences & Target site & Specificity & Reference \\
\hline $\begin{array}{l}\text { NSMR52f } \\
\text { (forward) }\end{array}$ & $\begin{array}{l}\text { TCA GAA AGA AAG AAT } \\
\text { CAT G }\end{array}$ & $\begin{array}{l}\text { Nitrosom-onas europaea- } \\
\text { like AOB }\end{array}$ & $\begin{array}{l}\text { (Burrell et al., } \\
\text { 2001). }\end{array}$ \\
\cline { 1 - 1 } $\begin{array}{l}\text { NSMR53r } \\
\text { (reverse) }\end{array}$ & $\begin{array}{l}\text { GTC TCC AYT AGA TTC CAA } \\
\text { G }\end{array}$ & $999-1,017$ & & \\
\hline
\end{tabular}

For confirmation and identification of microbial isolates of heterotrophic bacteria responsible for heterotrophic nitrification were done in the National Research Center, (NRC, Dokki, Gizza, Egypt.) using BIOLOG GN III system (BIOLOG, USA); where typical colonies of bacterial species were picked up from the surface of the specific chromogenic medium and identified using BIOLOG GEN III system (BIOLOG, USA). The GEN III MicroPlate ${ }^{\mathrm{TM}}$ test panel provides a standardized micro-method using 94 biochemical tests to profile and identify a broad range of Gram-negative and Gram-positive numbers (MPN) of nitrifying bacteria. $A O B$ selective medium was prepared by dispensing ingredients into reagent-grade water and adjusting $\mathrm{pH}$ to the range 7.8 to 8.1 with diluted $\mathrm{NaOH}$, allowing for $\mathrm{pH}$ changes during autoclaving, then autoclaving medium at $121^{\circ} \mathrm{C}$ for $15 \mathrm{~min}$. Tubes were incubated at 25 to $30{ }^{\circ} \mathrm{C}$ for 23 to 28 days for ammonia oxidizers. Incubation of the samples may be extended for several additional weeks until there are no additional positive reactions to recover the slow growing nitrifiers, after the prescribed incubation period, positive tubes were identified by looking for a $\mathrm{pH}$ change in the media (indicated by a color change from red to yellow) as a preliminary indicator of growth. Most probable number (MPN)/ml was calculated by using a standard MPN table. Although MPN values have been shown to underestimate the density of nitrifying bacteria, this method is useful for quantifying nitrifiers in water (APHA, 2005).

\section{Identification of responsible bacteria}

Nitrosomonas europaea was detected by CPCR with forward primer: NSMR52f and reverse primer: NSMR53r. Oligonucleotide primers were used according to (Burrell et al., 2001) with a specific sequence amplifying a specific product as shown in Table (1). bacteria. Biolog's microbial identification systems software (OmniLog ${ }^{\circledR}$ Data Collection) is used to identify the bacterium from its phenotypic pattern in the GEN III MicroPlate.

\section{Statistical analysis \\ The data were analyzed using statistical software (SPSS Version 17, SPSS INC, Chicago, IL, USA). Initially, the descriptive statistics were computed. One-way ANOVA was used followed by Duncan's post hoc test $(\alpha 00.05)$. In all tests, $p$ values smaller than $5 \%$ were considered statistically}




\section{RESULTS AND DISCUSSION Nitrogen characterization of Kafr El- Sheikh seven main canals:}

Figure 1 , shows ammonia values that ranged between $4.95 \mathrm{mg} / \mathrm{l}$ during winter season and $0.33 \mathrm{mg} / \mathrm{l}$ during summer season. However, the Egyptian limits for water resources ammonia concentration for drinking water production purposes is $0.5 \mathrm{mg} / \mathrm{l}$. Also, ammonia serves as a substrate for $\mathrm{AOB}$ and is considered one of the most important factors affecting nitrification process. Ammonia and nitrogen concentrations more than $1 \mathrm{mg} / \mathrm{l}$ have been given as indicator of organic pollution such as, sewage discharge, industrial effluents and agriculture-runoff. Nitrite values ranged between $0.52 \mathrm{mg} / \mathrm{l}$ during winter season and $0.1 \mathrm{mg} / \mathrm{l}$ during summer season.
Nitrite is an intermediate oxidation state of nitrogen, increased nitrite values during winter season might be attributed to decomposition of organic matter, increase of pollutants and oxidation of ammonia by AOB. Nitrate values ranged between $6.4 \mathrm{mg} / \mathrm{l}$ during winter season and $3.6 \mathrm{mg} / \mathrm{l}$ during summer season. Nitrate ion is the final oxidation product of nitrogen compounds in the aquatic environment. The low values of nitrate during summer season might be attributed to the uptake of nitrate by natural phytoplankton and its reduction by denitrifying bacteria while the increase of nitrate levels during winter season might be attributed to sewage wastes and low consumption of phytoplankton as well as the oxidation of ammonia by nitrifiers.

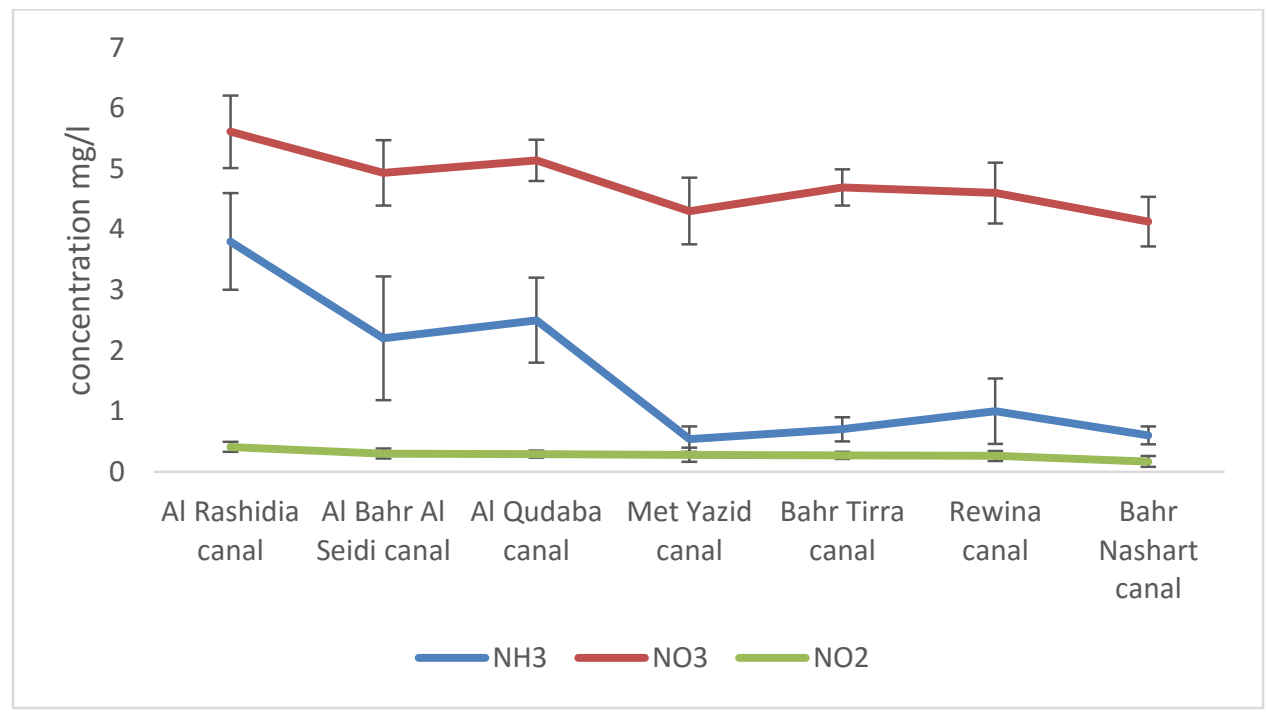

Figure (1): Nitrogen forms analyses of seven points on the seven major canals from December 2013 to October 2014 as annual average and standard deviation. 


\section{Bacteriological examination}

Bacteriological characteristics are still the primary water quality issue in any water resources especially those used in drinking purposes. Results presented in Figures 2, showed the seasonal and spatial variations of Total bacterial count and pollution microbial indicators as total and fecal coliforms and fecal

A

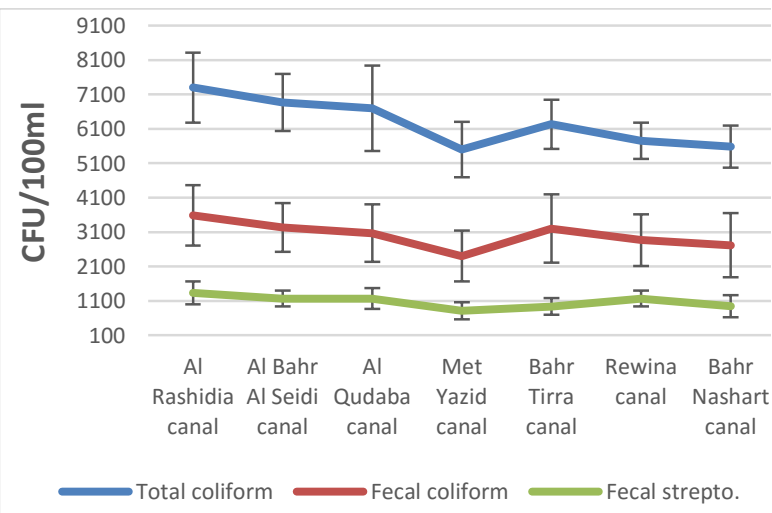

streptococcus from December 2013 to October 2014. The results of all microbiological parameters showed increase in winter season during low demand period while water level is decreased; increased counts might be attributed to domestic sewage, agricultural effluents discharge, and increased organic matter.

Figure (2): Microbial forms analyses of seven points on the seven major canals from December 2013 to October 2014 as annual average and standard deviation for pollution indicators (A) and total count (B).

Ammonia oxidizing bacteria (AOB) ranged from 1600 (MPN index-100 ml) during winter season to 12 (MPN index-100 $\mathrm{ml}$ ) during summer season. Increased counts of $A O B$ during winter season might be attributed to the increase of ammonia concentrations in raw water during that period. It was observed that all sites during the whole period of study recorded few points on Water

\section{Algal characterization:}

During the whole period of study, it was noticed that the highest value of Total Algal Count was recorded in Al Rashidia canal during winter season (December 2013) while the lowest Total Algal Count value was recorded in Rewina canal during summer season (August 2014). The differences between different canals in Total
Quality Index scale ranged from 34.36 to 43.52 indicating poor conditions of raw water resources. The lowest values were recorded during winter season indicating the effect of low demand period, decreasing of water level and increasing of pollutants during this period resulting in a deteriorated water situation.

Algal Count are small regarding the seasonal variation for each canal. Al Rashidia, Al Qudaba and Al Bahr Al Seidi canals showed the highest total algal count while Rewina and Bahr Nashart canals showed the lowest count. Total Algal Count increase markedly in winter season then started to decrease in spring and reached the lowest count in summer then began to increase again in autumn season; see Fig. (1). 


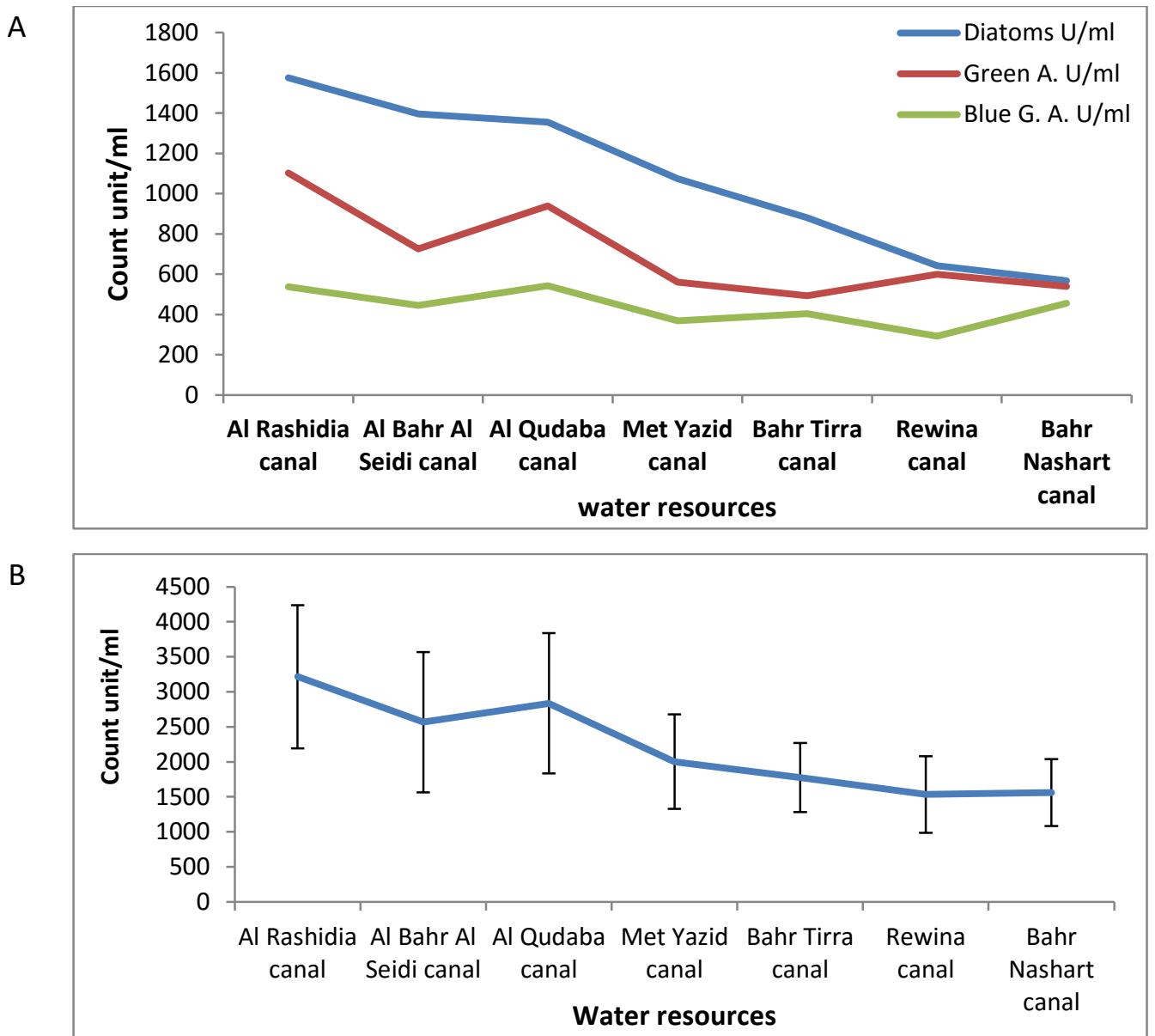

Figure 4, Annual average of Algal Count for seven points on the seven major canals from December 2013 to October 2014 as counts of units (A) and Total (B).

Correlation (predictive statistics) was carried out using SPSS analytical program to determine correlation coefficients between physical, chemical and microbiological parameters which proved that $\mathrm{AOB}$ and most physicochemical and microbiological parameters showed strong positive and high significant correlations between each other. Identification of ammonia oxidation and degradation responsible bacteria revealed that Nitrosomonas europaea and Bacillus amyloliquefaciens were involved in ammonia removal and nitrification process.
The present study offered detailed quality information about the seven main canals in Kafr El-Sheikh governorate that cover the major cities of the governorate and used as raw water resources by water purification plants for drinking water production. The study discusses seven points on the seven major canals from December 2013 to October 2014. The results presented in Table (2) showed the seasonal and spatial variations of temperature, $\mathrm{pH}$, Electric Conductivity and Total Dissolved Solids. In this study; physicochemical and

\section{Water quality characterization}


microbiological characteristics of raw water samples which were taken seasonally from selected sampling sites on the seven main canals in Kafr El-Sheikh Governorate were tested and studied for monitoring nitrification process occurrence and studying its effect on physicochemical and microbiological characteristics of water.

Phosphate values ranged between $1.78 \mathrm{mg} / \mathrm{l}$ during winter season and $0.32 \mathrm{mg} / \mathrm{l}$ during summer season. Phosphorus is an essential nutrient for all microbial growth including nitrifying bacteria, high concentrations of phosphate may indicate the presence of sewage pollution. Sulfate values ranged between $80.7 \mathrm{mg} / \mathrm{l}$ during winter season and $26.8 \mathrm{mg} / \mathrm{l}$ during summer season. High levels of sulfate indicate the excessive use of sulfate-rich fertilizers as well as domestic wastes.

Table (2) Annual average in $\mathrm{mg} / \mathrm{l}$ of chemical and physical characterization of water resources.

\begin{tabular}{|l||c|c|c|c|c||c|c|}
\hline \multicolumn{1}{|c|}{ Parameters } & $\begin{array}{c}\text { Al } \\
\text { Rashidia } \\
\text { canal }\end{array}$ & $\begin{array}{c}\text { Al Bahr } \\
\text { Al Seidi } \\
\text { canal }\end{array}$ & $\begin{array}{c}\text { Al } \\
\text { Qudaba } \\
\text { canal }\end{array}$ & $\begin{array}{c}\text { Met } \\
\text { Yazid } \\
\text { canal }\end{array}$ & $\begin{array}{c}\text { Bahr } \\
\text { Tirra } \\
\text { canal }\end{array}$ & $\begin{array}{c}\text { Rewina } \\
\text { canal }\end{array}$ & $\begin{array}{c}\text { Bahr } \\
\text { Nashart } \\
\text { canal }\end{array}$ \\
\hline \hline Temp $\left({ }^{\circ} \mathrm{C}\right)$ & 22.8 & 23.2 & 23.4 & 22.8 & 22.95 & 23.1 & 23.1 \\
\hline \hline $\mathrm{pH}$ & 7.98 & 7.8 & 7.9 & 7.9 & 7.95 & 7.84 & 7.87 \\
\hline \hline Cond $(\mu \mathrm{S} / \mathrm{cm})$ & 631 & 592.5 & 435.2 & 435.5 & 420.7 & 433 & 419 \\
\hline \hline TDS & 429.3 & 403.3 & 293.8 & 291.7 & 284.7 & 291.3 & 281.5 \\
\hline \hline Turbidity & 14.82 & 10.15 & 11.45 & 9.41 & 9.8 & 8.82 & 7.97 \\
\hline \hline Alkalinity & 215.3 & 202 & 183.3 & 168 & 174.7 & 171.3 & 172 \\
\hline \hline Total Hardness & 191.3 & 201.3 & 169.3 & 158.7 & 164.7 & 162.7 & 150.7 \\
\hline \hline Ca. Hardness & 128.3 & 133.7 & 112.3 & 106 & 108.7 & 107.7 & 101.7 \\
\hline \hline Mg. Hardness & 63 & 67.7 & 57 & 52.7 & 56 & 55 & 49 \\
\hline \hline Chloride & 70.3 & 61.7 & 31 & 38.7 & 34.3 & 36.7 & 31.7 \\
\hline \hline Phosphate & 1.045 & 0.888 & 0.475 & 0.637 & 0.508 & 0.618 & 0.733 \\
\hline \hline Sulphate & 61.280 & 65.780 & 36.420 & 39.740 & 38.000 & 40.380 & 39.680 \\
\hline
\end{tabular}

- Means with the same letter(s) of the same parameter are not significantly different at $p \geq 0.05$.

- Data are represented as Mean \pm Standard error.

- Number of observations in each mean $=5$

Identification of heterotrophic bacteria involved in nitrification

One bacterial strain isolated from $A O B$ broth medium and purified on TSA medium was identified as Bacillus amyloliquefaciens using BIOLOG GEN III MicroPlate system by National Research Centre (NRC), El Buhouth, Dokki, Cairo, Egypt, see Fig. (46). Two bacterial strains isolated 
from $A O B$ broth medium and purified on TSA medium were identified by CPCR and BiologGENE III system. Nitrosomonas europaea-like $A O B$ were detected with primer pair NSMR52f and NSMR53r for identification of bacteria responsible for Ammonia oxidation in Freshwater Aquaria, which proved the existence of Nitrosomonas europaea-like $\mathrm{AOB}$ in the sample, see Fig. (5).

\section{(A)}

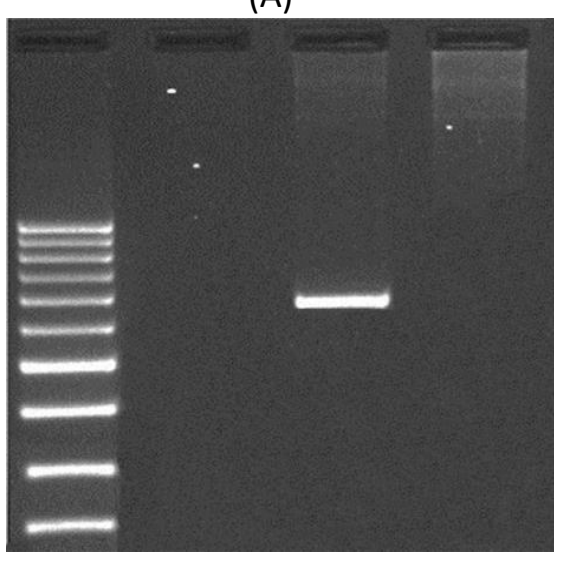

\begin{tabular}{||l|l|}
\hline Organism Type & GP-Rad-SB \\
\hline Family & Bacillaceae \\
\hline Species & Bacillus amyloliquefaciens \\
\hline Protacal & A. \\
\hline
\end{tabular}

Average Maximum Pasitive [Graphic with $80 / 20$ Cutoff]

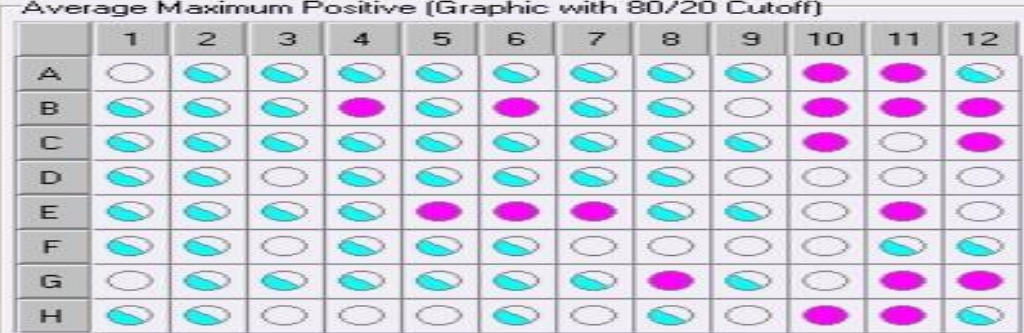

\begin{tabular}{|c|c|c|c|c|c|c|c|c|c|c|c|c|}
\hline \multicolumn{13}{|c|}{ Average Maximum Positive [Percent] } \\
\hline & 1 & 2 & 3 & 4 & 5 & 6 & 7 & 8 & 9 & 10 & 11 & 12 \\
\hline A & $\mathbf{O}$ & 76 & 74 & 79 & 78 & 79 & 75 & 75 & 69 & 100 & 98 & 51 \\
\hline $\mathbf{B}$ & 70 & 73 & 51 & 80 & 75 & 80 & 37 & 21 & o & 96 & 90 & 87 \\
\hline C & 69 & 70 & 72 & 59 & 32 & 32 & 25 & 29 & 66 & 97 & 18 & 90 \\
\hline$D$ & 78 & 73 & 0 & 23 & 74 & 23 & 36 & 72 & 8 & 15 & 18 & 8 \\
\hline$E$ & 76 & 73 & 77 & 67 & 82 & 82 & 80 & 71 & 69 & 18 & 86 & 8 \\
\hline F & 73 & 39 & 0 & 77 & 39 & 40 & 16 & 8 & 20 & 17 & 29 & 28 \\
\hline$G$ & 3 & 63 & 24 & 79 & 49 & 39 & 73 & 82 & 67 & 18 & 82 & 100 \\
\hline$H$ & 58 & 47 & 15 & 5 & 0 & 78 & 16 & 77 & 19 & 83 & 85 & 38 \\
\hline
\end{tabular}

Figure 5: identification of Nitrosomonas europaea by Conventional PCR (A) and Identification of Bacillus Amyloliquefaciens using BIOLOG GEN III MicroPlate system (B).

Finally, this study discussed nitrification as a biological process for ammonia removal proposing an infield solution of ammonia increase in water, this study also recommends proceeding of research and further investigation for the development of this biological process and making it possible to be applied in raw water resources to find an effective and efficient solution for ammonia problems in raw water resources. 


\section{References}

1. Mook, W.T. Chakrabarti, M.H. Aroua, M.K. Khan, G.M.A. Ali, B.S. Islam, M.S. Abu Hassan, M.A. Removal of total ammonia nitrogen (TAN), nitrate and total organic carbon (TOC) from aquaculture wastewater using electrochemical technology: A review. Desalination 285 (2012) 1-13.

2. Afonso, M.D. Jaber, J.O. Mohsen, M.S. Brackish groundwater treatment by reverse osmosis in Jordan, Desalination 164 (2004) 157-171.

3. Kim, Y.M. Kim, S.J. Kim, Y.S. Lee, S. Kim, I.S. Kim, J.H. Overview of systems engineering approaches for a large-scale seawater desalination plant with a reverse osmosis network, Desalination 238 (2009) 312-332.

4. Hilal, N. Al-Zoubi, H. Darwish, N.A. Mohammed, A.W. A comprehensive review of nanofiltration membranes: treatment, pretreatment, modelling, and atomic force microscopy, Desalination 170 (2004) 281-308.

5. Sheldon-Coulson, G.A. Production of levulinic acid in urban biorefienries, in: Master Thesis, Institute of Technology, Massachusetts, 2011 (accessed December 2014) http://dspace.mit.edu/bitstream/handle/1 721.1/68450/769021899-

MIT.pdf?sequence $=2$.

6. Nielfa, A. Cano, R. Fdz-Polanco, M. Theoretical methane production generated by the co-digestion of organic fraction municipal solid waste and biological sludge, Biotechnol. Rep. 5 (2005) 14-21.

7. Wagner, O.A. Lins, P. Malin, C. Reitshuler, C. Illmer, P.Impact of protein- lipid-and cellulose-containing complex substrates on biogas production and microbial communities in batch experiments, Sci. Total Environ. 458-460 (2013) 256-266.

8. Verma, S. Anaerobic digestion of biodegradable organics in municipal solid wastes, in: Master Thesis, Columbia University, 2002 http://www.seas.columbia.edu/earth/ver mathesis.pdf.
9. Xue, W. Wu, C. Xiao, K. Huang, X. Zhou, $\mathrm{H}$. Tsuno, H. Tanaka, H. Elimination and fate of selected micro-organic pollutants in a full-scale anaerobic/anoxic/aerobic process combined with membrane bioreactor for municipal wastewater reclamation, Water Res. 44 (2010) 59996010.

10. Sanguanpak, S. Chiemchaisri, C. Chiemchaisri, W. Yamamoto, K. Effect of organic fouling on micro-pollutant rejection in membrane bioreactor treating municipal solid waste landfill leachate, Water Sci. Technol. 72 (4) (2015)561571.

11. Boonnorat, J. Chiemchaisri, C. Chiemchaisri, W. Yamamoto, K. Microbial adaptation to biodegrade toxic organic micro-pollutants in membranebioreactor using different sludge sources, Bioresour. Technol. 165 (2014) 50-59.

12. Boonyaroj, V. Chiemchaisri, C. Chiemchaisri, W. Yamamoto, K. Enhanced biodegradation of phenolic compounds in landfill leachate by enriched nitrifying membrane bioreactor sludge, J. Hazard. Mater. (2016). http://dx.doi.org/10.1016/j.jhazm at.2016.06.064.

13. Konuma, S., H. Satoh, T. Mino and T. Matsuo. "Comparison of enumeration methods for ammonia-oxidizing bacteria." Water science and technology 43(1) (2001) 107-114.

14. Sanden, B., C. Grunditz, Y. Hansson and G. Dalhammar. "Quainification and Characterisation of Nitrosomonas and Nitrobacter Using Monoclonal Antibodies." Water science and technology 29(7) (1994) 1-6.

15. American Public Health Association [APHA] (2005) Standard Methods for the Examination of Water and Wastewater $22^{\text {nd }}$ ed. APHA, Inc. Washington, D.C.

16. Burrell, P. C., C. M. Phalen and T. A. Hovanec (2001). "Identification of bacteria responsible for ammonia oxidation in freshwater aquaria." Applied and environmental microbiology 67(12): 5791-5800. 